\title{
EXPERIMENTAL LABORATORY TOOLING FOR DEEP DRAWING PROCESS
}

\author{
Ing. Alexander SCHREK, PhD., Ing. Michal ČINÁK, Ing. Peter Žitňanský, PhD.
}

Institute of technologies and materials, Pionierska 15, 83102 Bratislava, Faculty of Mechanical Engineering, Slovak University of Technology in Bratislava.

\begin{abstract}
New trends in the deep drawing of tailored blanks demands for the analysis of process parameters and their setup to obtain the drawn parts with required shape precision, strength and stiffness. One option is to perform the experiments, measurements and optimization of that process on an experimental laboratory device and to compare the results to those from simulations. This contribution deals with the redesign of a device that is used at the Institute of technologies and materials with regard to replacement of strain gauge force measuring system by piezoelectric force measuring system. The new design is also focused on a new way of setting the blankholder pressure applied on the tailored blank.
\end{abstract}

KEYWORDS: Deep drawing process; Experimental tooling; Elastic blankholder pressure distribution

\section{DESCRIPTION OF A PREVIOUS SOLUTION}

At the Institute of technologies and materials in last period we have been studying the problem of the optimization of deep drawing process parameters. For the deep drawing processes research and investigation of the formability of different materials a special experimental tooling was designed and installed on hydraulic double-acting press PYE $160 \mathrm{~S}$. The configuration of the device is so-called "inverted - single-action drawing with a draw cushion". The forming force is exerted by the slide above through the die and the blankholder onto the cushion in the press bed. The draw punch and the blankholder of the drawing tool are both located in a base plate on the press bed. Eight pressure pins, which come up through the press bed and the base plate transfer the blankholder force from the draw cushion onto the blankholder. [1] Four of them, in symmetric $90^{\circ}$ configuration, were equipped with the load cells. The die with three load cells is mounted on the press slide. The blankholder plate is designed to be elastic enough to allow the adjustment and the control of the blankholder pressure distribution by means of eight height adjustable pressure pins [2]. The pressure distribution was controlled by elongation or shortening of the pressure pins between the cushion and the blankholder plate via bolts and lock nuts screwing them back or in. Measurements of drawing process forces on the draw punch, die and blankholder were executed by means of load cells with glued strain gauges HBM 6/120LY11 according to Fig.1. 


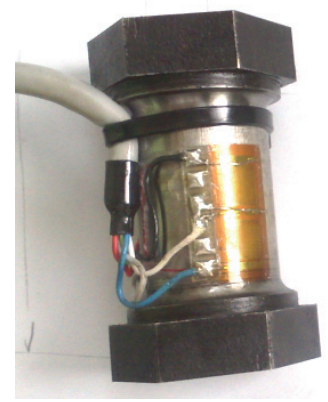

Fig.1 Load cell with glued strain gauges HBM 6/120LY11

The slide stroke was registered by the rectilinear displacement transducer RC $20-250$. The measured values were processed by means the eight-channel measuring system Conmes Spider and evaluated in the Conmes Spider 14.0.4 software. The entire configuration of the experimental device is shown in Fig. 2.
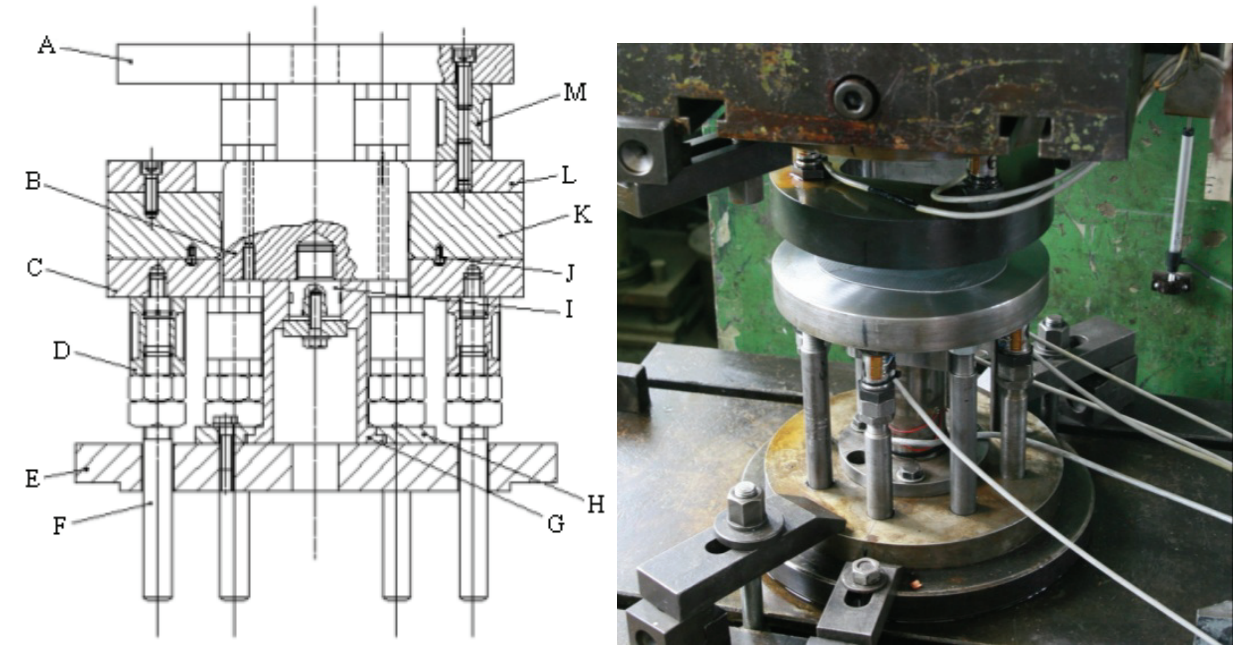

Fig. 2. Laboratory experimental tooling for measuring process parameters of deep drawing [3] $A$ - base plate, $B$ - punch, $C$ - blankholder, $D$-pressure pin load cell, $E$-lower base plate, $F$ - pressure pin, $G$-punch support, $H$ - support holder, $I$ - punch fixture, $J$-position pin, $K$ - die, $L$ - insert, $M$ - die load cell

\section{THE REDESIGNED CONCEPT}

Experimental operation of the original equipment detected problems with parameters setup. The adjustment of required uniform or non-uniform distribution of blankholder pressure was difficult and time-consuming. The final uniform adjustment was often a lucky occurrence. That is why there was a suggestion to redesign the tooling also with regard to replacement of strain gauge load cells by more precise and accurate piezoelectric load cells HBM KMR/300 kN from Hottinger Baldwin Messtechnik GmbH. 
Out of several feasible alternative concepts the one was chosen that did not require strong modification of tooling active parts (draw punch, die, blankholder plate). The manufacturig only new force transmitting parts was needed allowing the seven new piezoelectric sensors (Fig. 3 ) to be built in (4 on the blankholder, 3 on the die).

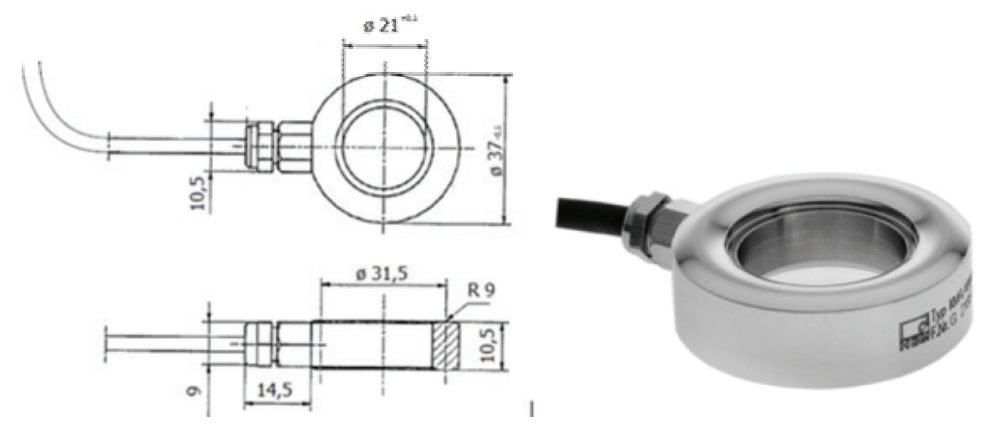

Fig. 3. Piezoelectric washer HBM KMR/300 kN [4]

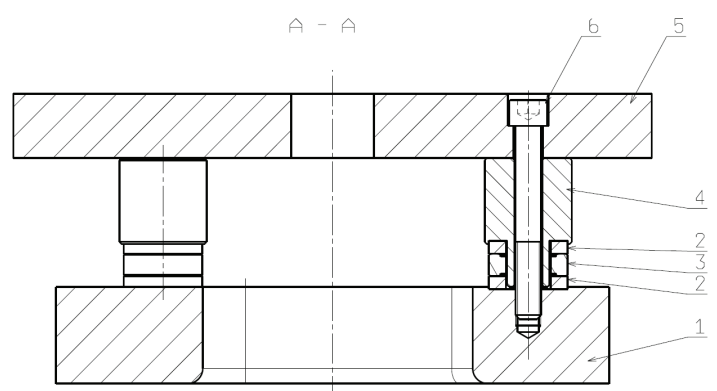

Fig. 4 Configuration of the die, measuring elements and base plate [5] 1) die plate, 2) KMR washer, 3) KMR load cell, 4) transmission column, 5) base plate, 6) bolt

As it can be seen in the Fig. 4 three columns include sensors and serve the fixation of the die to the upper base plate. The space between die and upper base plate whose width is determined by the dimensions of the elements $2,3,4$, enables to take the drawn part out of the tooling. The height of the part is about $40 \mathrm{~mm}$. The columns were made of heat treated 14231 steel CSN 414231 (or 30ChGT GOST 4543-71).

The blankholder plate did not require any reconstruction works. It fits together with all new parts according to the Fig. 5 also made of 14231 material. The height adjustment of the pressure pins is enabled by threaded joints and quenched washers that are fine machined to defined thickness. These washers prevent prestressed threaded joints from force transmission. Other advantage of this solution is the equal deformation of all 8 pressure pins (with or without load cells). The pressure pins without load cells contain identical stiffness substitution elements made of 19721 steel CSN 419721 (X30WCrV93 EN 96-79 or 3Ch2V8F GOST 5950-73). Possible disadvantage is that many washers of various thicknesses are needed to achieve required height adjustment of the pressure pins. 


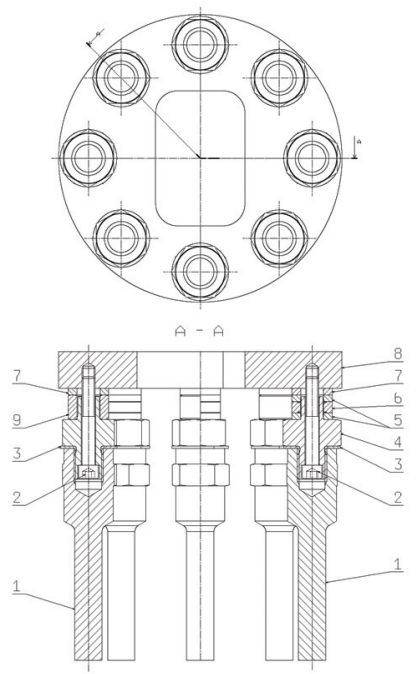

Fig. 5 Configuration of the blankholder with transmission pressure pins [5] 1) pressure pin, 2) bolt, 3) washer, 4) joining element, 5) washer KMR, 6) $K M R$, 7) ring, 8) blankholder plate, 9) substitution element for KMR

\section{FUNCTION VERIFYING AFTER RECONSTRUCTION}

All new parts were manufactured according to the documentation at the Institute of Technologies and Materials and at the Centre of Innovations of the Faculty of Mechanical Engineering, Slovak University of Technology in Bratislava. The tooling was assembled in accordance with the documentation and was installed on the hydraulic press PYE $160 \mathrm{~S}$. The whole assembly with the measuring apparatus is shown in the Fig. 6.

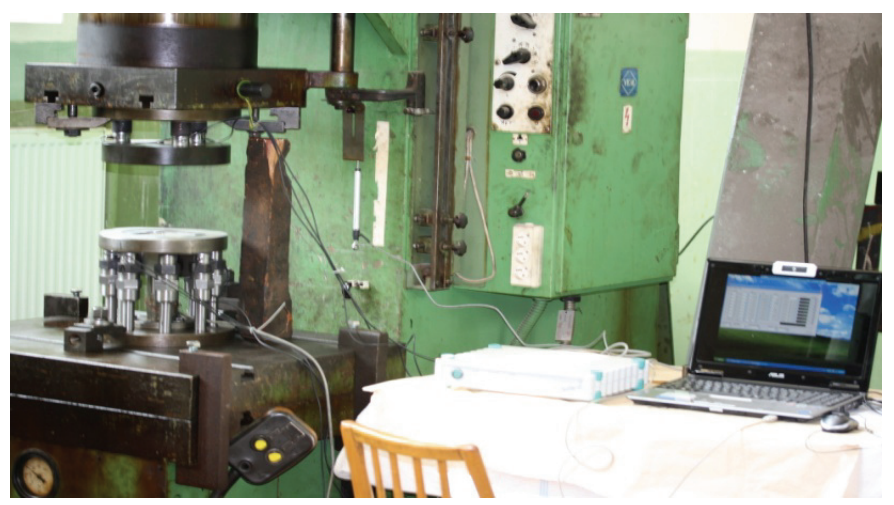

Fig. 6 Laboratory experimental tooling with the measuring apparatus

Every measuring element and its connector were marked in accordance with their position in the tooling. The connectors were plugged to the measuring system Conmes Spider and by means of USB reduction to the PC where the signal input was processed in the software environment Conmes Spider 14.0.4. 
Correct function of each measuring element is ensured by calibration that can be executed manually or "functionally". Functional calibration is set up during the static compression test. Manual calibration can be set up by entering the sensor sensitivity known from the producer. For the $\mathrm{KMR} / 300 \mathrm{kN}$ it was the value $80 \mathrm{mV} / \mathrm{V}$. In the Fig. 7 there is Conmes Spider 14.0.4 software environment right after the calibration in the moment of resetting.

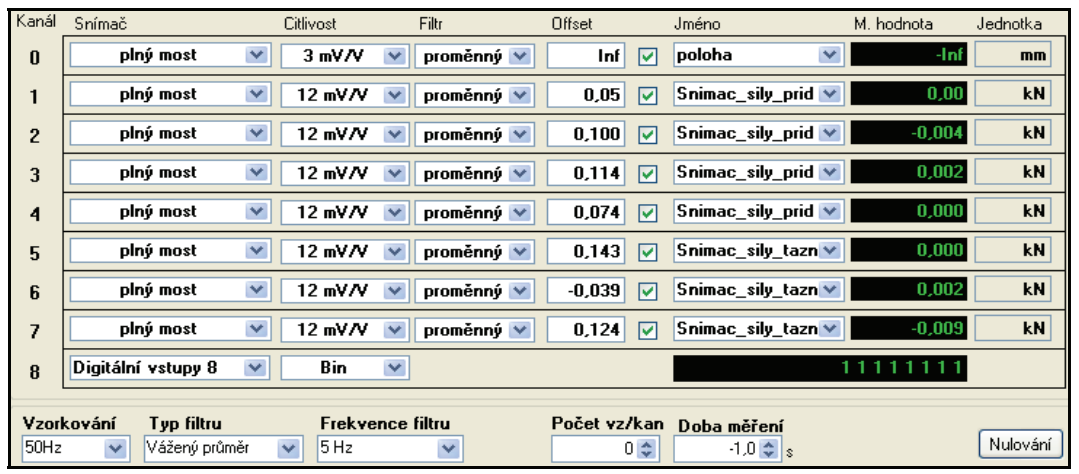

Fig. 8 Main environment of the Conmes Spider 14.0.4 software

\section{STROKE WITHOUT BLANK}

For testing a setting the measurement function there were planned two modes. First mode without blank that is for testing the basic setup and the second mode for testing with blank. During the first mode, the measuring system records the forces through the KMR sensors of die and blankholder pressure pins since die pushes the blankholder downward against the upward acting force of the draw cushion. The slide stroke is registered by the displacement transducer and all time relationships are represented in Fig. 8

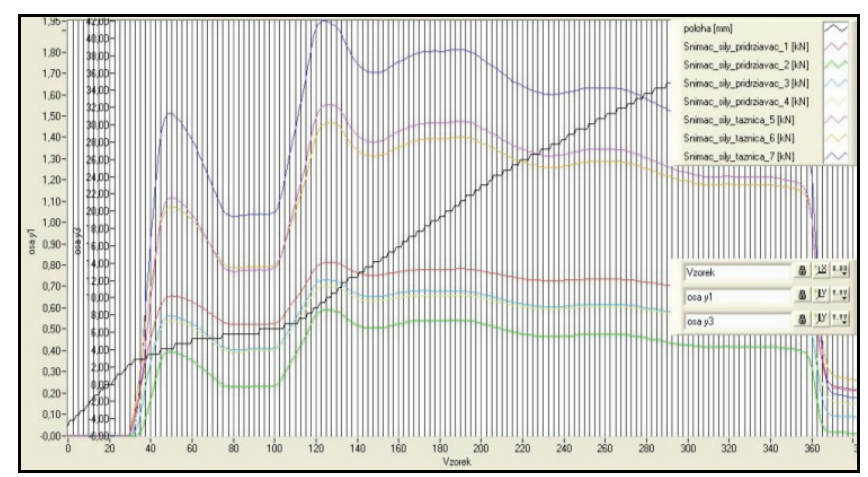

Fig. 8. Blankholder - versus time and die force - versus time relationships while testing without blank

The differences between blankholder force curves are proving incorrect set up of the tooling. Characteristics are not constant that may be caused by non-uniform movement of the slide (black increasing curve). The registered variations prove good sensitivity of piezoelectric force measuring system. The force - stroke curves (Fig. 9) are of stable - quasi constant form. 


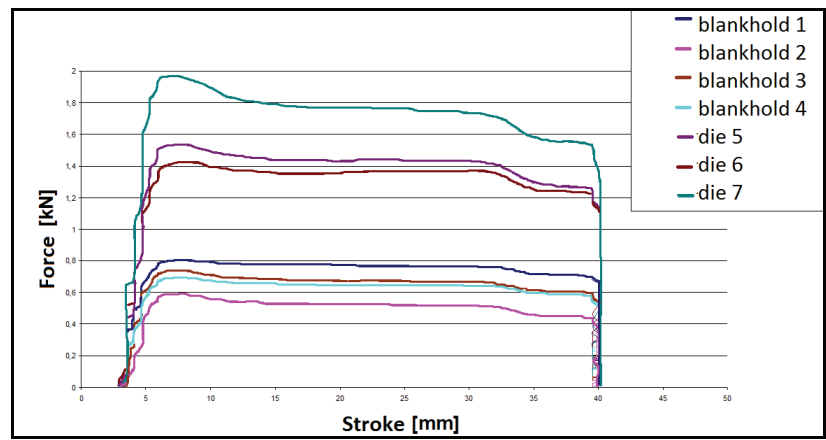

Fig. 9. Force-stroke relationships at non-uniform blankholder pressure distribution

\section{STROKE WITH BLANK}

After adjusting the height of the pressure pins, the blank was put in the tooling to perform the deep drawing operation. The force-stroke curves are represented in the Fig. 10. Uniformity of the pressure distribution is in range of about $10 \%$. The punch force can be calculated from the sum of the punch and blankholder forces that equals the sum of the die forces.

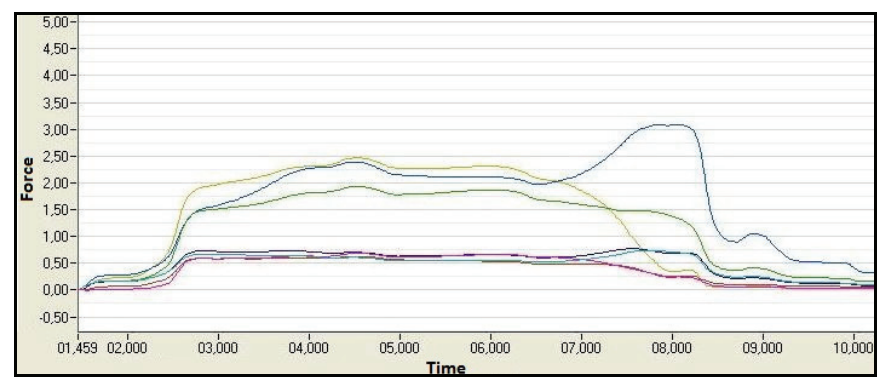

Fig. 10 Force-stroke curves after setting up the uniform pressure distribution

In the Fig. 11 there is a force - stroke curves with eliminated influence of the velocity. Measured characteristics of die (three upper curves) are influenced drawing condition, drawing gap, lubrication, blank holder wearing. The sensor No. 6 of die plate signalizes a significant increase of the force at the end of the stroke, which is strengthened by simultaneous moderate decreasing of force on sensor No. 5 and strong decreasing on sensor No. 7. It is caused by an ear forming at the drawn part corner (Fig. 12) due to possible eccentric positioning of the blank or displacement caused by blankholder surface wearing or too wide drawing gap. However presented measurements show the good functionality of the advanced tool design and reliability of the new measuring system. 


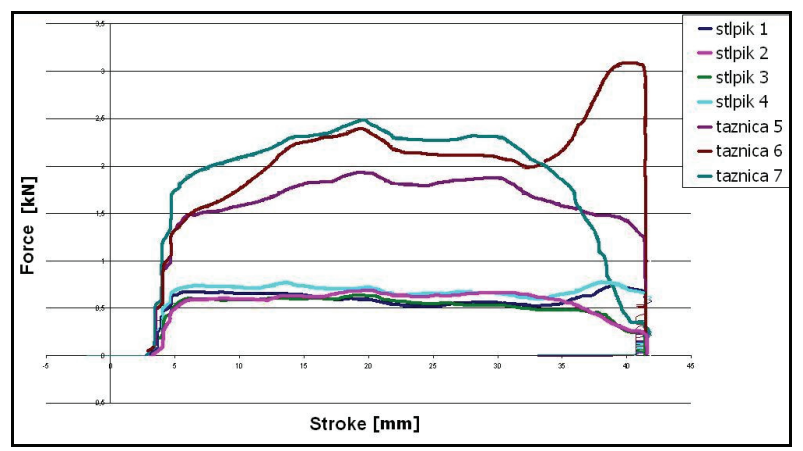

Fig. 1. Die force-stroke and blankholder-stroke relationships at non-uniform blankholder pressure distribution

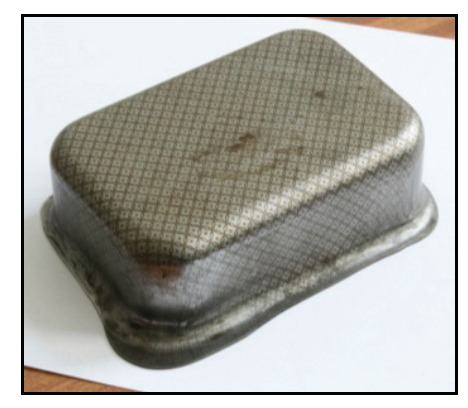

Fig. 12 Deep drawn part with ear at the corner

\section{CONCLUSION}

By means of this successful redesign of the tooling, we have obtained a device of a better quality of measuring drawing and blankholding forces with their uniform or non-uniform distribution in time and slide stroke relation. This device enables to effectuate planned measurements on tailored blanks that are composed of different materials of different thicknesses and different formability during controlled working conditions. Thanks to this, it will be possible to determine the conditions for drawing the parts of required dimensional and shape accuracy, strength level and stiffness quality.

\section{REFERENCES}

[1] CEKAN, P.: Computer Simulation of Deep Drawing Processes, Slovak University of Technology, Bratislava, May 2005.

[2] ŽITŇANSKÝ, P., KOSTKA, P., SCHREK, A.: Deep Drawing of Combined Tailored Blank from High-strength Steel, Hutnické listy - Metallurgical Journal, vol. LXIII, 2010, (61-64)

[3] ŽITŇANSKÝ, P.: Simulácia tvárnenia súčiastok z plošných polotovarov novej generácie, Dizertačná práca, Ústav technológií a materiálov SjF STU Bratislava, 2009.

[4] Manual for piesoelectric washer HBM KMR/300 kN - Hottinger Baldwin Messtechnik GmbH

[5] DEMETER, M.: Experimentálny laboratórny nástroj pre plošné tvárnenie, Diplomová práca, Ústav technológií a materiálov SjF STU Bratislava, Jún 2011 